\title{
5. Holding the line? Keeping independent may be a close-run thing for media in PNG
}

\section{ABSTRACI}

This investigation deploys journalistic expertise and method to bring information about media and government relations in Papua New Guinea up to date. The researcher identifies the news agenda by means of a press review over two weeks; discusses the issues raised with informed interviewees from government, media and universities; and checks the information against published research. The report traces a tense media-government relationship, marked by mutual recrimination over access to information. While government observes principles of free speech, and dayby-day relations are cordial, there have been recurrent moves towards regulation of news media, and many instances of intimidation of journalists. A general context of economic stress, official corruption, and violence exacerbates negative feelings, despite efforts on both sides to maintain détente. The relationship is seen heading towards a possible show-down over Rimbunan Hijau, the timber company widely accused of environmental crimes, abuse of citizens and corruption of high officials.

\section{LEE DUFFIELD}

Queensland University of Technology

\section{Introduction}

7 HE UNEASY state of relations between the political community in Papua New Guinea and its 'fourth estate' is an on-going contest over

unresolved issues. The problems of governing in PNG generally, especially problems of the economy, public order and corruption, are an urgent concern of journalists; so the relationship is marked by demands for infor- 
mation from the government, never met to the satisfaction of the news media; tendencies towards imposing controls on media, and harassment or obstruction of media organisations and their employees.

When the situation was reviewed for this report, a new show-down looked to be on the way, over the activities of the Malaysian-based forest logging company Rimbunan Hijau. The company has become notorious through repeated accusations against it of malpractice, in its timber logging practices, treatment of local employees, and use of its privileged access to politicians; accusations widely broadcast in international media and traded more cautiously but persistently within the country. For journalists it has aroused once more concerns over availability of information, standards of governance, order and human rights at the heart of recurrent serious disputes with government; never as yet reaching the point of open and ongoing hostility, never quite being settled.

\section{Background to research}

Government in Papua New Guinea shows signs of exasperation with its situation, having to manage crisis on a daily basis: an uphill battle to finance development needs and community services; destructive crime in village communities and urban settlements; official corruption, and linked to that irresponsible behaviour among some of the political leadership itself. Large sums of money seemed to be in some private hands, for instance from out-of-court settlements received by litigants against the government, often in hundreds of thousands of kina ( $\mathrm{\$} 1=\mathrm{K} 2$ approx.), while there is widespread poverty in the 'informal sector' (AusAID 2004, p. 13).

News media equally have an exasperating time, beginning with the demand for coverage of crisis situations and high risks - including health and safety concerns with staff. It is a struggle to break even financially. They experience the standard impediments to doing business in developing countries, listed by the World Bank:

uncertainty over government policy; corruption; high costs associated with crime and security issues, including theft of stock, reducing sales constantly by 10 percent; infrastructure problems such as uncertain electricity supply costing another 10 percent of sales. (Smith, 2004)

Despite the pressure to go into dispute, civility exists between media and 
government. They can find themselves criticised as a 'cosy elite', if prone to quarrels. On one hand, with whatever blind-spots, despite all difficulties, government refrains from official censorship and expressly observes the freedom of all citizens under the law, represented in the national constitution, Section 46 (1975). On the other hand news media, striving to be 'free and fair' in the liberal tradition, also say they respect local tradition and make a commitment to national development objectives.

\section{Research methodology}

\section{Method}

This inquiry was the outcome of a working visit to Papua New Guinea in September-October 2004, involving teaching and research. It is journalistic in approach, intended to bring up to date the main points in an on-going media-government contest. It started with an intense 'reading-in' of PNG media and depends on extensive interviews, with some privileged access to informants in government, journalism and universities.

The method of inquiry was to observe PNG news media, including a systematic review of 16 issues of the two national daily newspapers, and to conduct interviews with 15 informed people, participants in some way in the interchange of media and government. The media review described an agenda of issues; the interviews produced a commentary on these issues and others affecting journalists' work. The process enabled some general conclusions to be made about the state of relations and future prospects.

\section{Interviews}

Interviews were obtained with a Minister in the government and one other senior government officer; editors from the principal news media outlets; academic commentators; two Australian foreign correspondents and an officer from the Australian High Commission. A panel of advanced level journalism students closed the discussion with an open commentary on the tensions between government agencies and media workers, being very circumspect on what their future might hold.

\section{News media under review}

In the formal media sector, the two daily newspapers, the Post-Courier (News Limited, Australia) and The National (Rimbunan Hijau, Malaysia), provide 
the most comprehensive record directly to hand. The weekly Wantok, owned by a churches consortium, publishes in Tok Pisin. Papua New Guinea has one television service, EM-TV (PBL Australia-owned at the time of survey, now owned by Fiji Television Ltd); a national radio broadcaster, NBC; two main commercial radio services (overseas interests, Fiji and elsewhere), and community radio services, mostly church-owned. The BBC and Radio Australia have their own frequencies in Port Moresby and RA programmes are carried on PNG regional stations, (AusAID 2004, pp.16-17). There is satellite television, also Australian-based, in limited use.

The review of The Post-Courier and The National, from 8 to 30 September 2004 inclusive, was to note the news agenda and obtain an indication of the intensity of interest in particular issues. Categories were inferred from the media coverage, which could also have been anticipated from an introductory knowledge of PNG current affairs:

- A concern with formal standards of economic management being met, off-set by a sense of financial and economic crisis. This took in concerns from a technocratic perspective that standards of efficiency and probity were failing, and concerns about infrastructure being inadequate and not maintained (44 reports).

- Development news, and foreign development assistance (97).

- News about the HIV-AIDS campaign, treated as a development issue (44).

- Official corruption and misconduct (96).

- Crime and the law and order issue (65).

- Human interest and community activities (18).

- Environmentalism, and the Malaysian timber company Rimbunan Hijau (RH). News about the controversial activities of RH, and the timber industry generally, came in the context of stories about forest protection (11).

- Relations with Australia, security and governance. Here there were linkages of ideas about Australians and their activities, and so disparate issues fell into the category with Australia as a unifying theme: some antiAustralian sentiment; Australian connections on security issues like terrorism; pressure from Australia to see good governance standards (27).

- Newspaper promotional campaigns and opinion (20). 


\section{Media content}

More than 422 news items or features were read and classified, indicating great variety in the coverage; high activity in the community frequently reflecting optimism about the future; and transparency in public life. Contents and tone of the stories give the impression of essentially a free culture suffering many anxieties. The study matches observations of Rooney (2003a, pp.1247) in a similar two-weeks' review, that a main focus of sourcing is on 'primary definers' (e.g. official sources in Parliament or the courts, often enough providing strong news). News about ordinary people, often more labour intensive and demanding to gather, can be under-represented by comparison. (The above count of stories, as it concentrated on media and government contact, did not extend to sports, gossip and entertainment sections; so 'human interest and community activities' and 'opinion' involving members of the general public would be a little higher than these figures indicate).

\section{National financial standards, and crisis (44 items)}

The news media as represented by the two newspapers acted as serious journals of record on government activities, pursuing reduced budget deficits and IMF compliance, but embarrassed by the consequences of budget shortfalls. Here most main stories of the day were duplicated in the two newspapers and editorial comment generally supported national policy. Forty-four stories were noted on these concerns about the economy, state finances and management.

Sample of contents:

The Treasurer proposed a 'tough budget' of spending constraint; and identified increased tax receipts and improved foreign exchange reserves, following higher export prices. Reports from a National Development Forum had senior civil servants talking of more fiscal sustainability. Pronouncements for Independence Day, 16 September 2004, included the Prime Minister, Sir Michael Somare, amid well-used photo opportunities in villages, pointing out real levels of developmental progress over the decades. Much of the Independence Day rhetoric however was themed on 'problems', Somare himself lamenting the three-tier system of government had failed to help the provinces, and warning that excessive population growth would prevent future delivery of services.

Well over half these news reports were negative, dealing with discord over policy or something going wrong with government services. The Acting 
Treasury Secretary saw debt burdens continuing to 'cripple' the national budget; the Internal Security Minister objected to postponement of a crucial national summit on guns; and it was admitted the police budget would be cut by 20 percent, senior officers hoping to reduce outlays on litigation against police.

\section{Development news (97)}

This large category answers demand for 'good news', favoured by governments, on economic advancement, especially in rural areas. The items were evenly divided between the newspapers, The National (53), the Post-Courier (44).

Most items were about small scale projects, in the context of broader programmes, including: WHO reporting on good management of PNG health services; AusAID support for roads projects and school buildings; transport subsidies to get coffee crops to market. Stories were supported by ample picture coverage, e.g. groups in midwifery classes; turning on a new water supply; MPs or Ministers cutting the ribbon. Much of this material was carried in regional supplements published regularly by both outlets, as the main, but not only space given to outer areas.

Twelve of the stories could be called negative on development, for instance: Structural failures of the Markham Bridge at Lae; delays with a regional water project; shortage of medicines.

The government has commenced publishing an occasional twelve-page supplement called Gavamani Sivarai, on development issues, through The National and the weekly Wantok. It is conservatively laid out, carrying long media releases and featuring Ministers heavily.

$H I V$-AIDS campaign (44)

With PNG the worst-affected country in the Pacific region, media reports support a sophisticated Australian-funded publicity campaign; overwhelmingly a project of the Post-Courier with 35 out of 44 reports counted.

Corruption issues, misconduct (96)

The public record revealed the seriousness of this burden, 96 stories, the Post-Courier (50), The National (46). Almost all were from open sources, in the courts or Parliament, or used statements by officials; there was little evi- 
dent need for anonymously sourced or other 'investigative' material given that the official record was keeping them running. The pressure on media resources is obvious, given the plethora of cases and problems with litigation, vexatious or otherwise.

\section{Contents:}

The senior public service law officer, Attorney General Francis Damem, was summonsed by the Public Service Commission on 22 September 2004 to answer charges that he drew a large commission out of an out-of- court settlement of K5 million. Ten stories.

A suspended Madang MP Peter Yama pleaded guilty to seven of 34 charges in the Leadership Tribunal which included misconduct in office in relation to the use of water and drought relief funds, rural transport money and funds for law and order.

The former National Gaming Board Chairman Daniel Mapiria was found guilty of misappropriating K3.188 million but freed on an undertaking to make substantial restitution.

The proposed sale of shares in the Telekom monopoly was stopped by the government while the Ombudsman's Commission investigated the process. The Communication Minister bought full page advertisements to vouch for the investigation against Opposition demands for a formal public inquiry.

The National Court dismissed bribery charges against the Milne Bay Governor, Tim Neville, citing lack of evidence, the MP declaring he would sue in retaliation.

Two MPs were before courts charged with misappropriating funds, in one case K56,000; criminal charges against a former MP over alleged misappropriation of K50,000 were quashed; a former National Provident Fund Chairman was defending charges of fraud; the Rural Development Bank was suing a former chairman over K200,000 paid to himself; and the budgets of three government bodies including National Fisheries were being investigated.

News reports had a country MP involved in gunplay as he negotiated the return of his vehicle, appropriated by local residents; another MP was accused of threatening to shoot somebody; a senior Member was in court, charged with shooting his wife, later discharged on grounds her affidavit of evidence had not been properly filed by police.

There were 12 reports about illegal use of horse racing machines for gambling. The taxation authority estimated this was costing K44 million in 
lost state revenue. Side issues included weak port security, with machines brought in illegally, and immigration rackets, most of the accused being Asian.

Several complaints about corruption appeared in letters columns referring to these cases.

Crime, law and order (65)

Reports fell into three sections: spot news, running stories, and commentary about law and order issues; approximately the same number of stories in each category, and from each newspaper- 65 in all.

Random incidents would involve individuals under stress, and group trouble among traditional clans or urban gangs: teenage boys jailed for a pack rape near Port Moresby; a woman shot dead by a household intruder in Lae; PNG Power employee murdered and body dumped at his Mt Hagen home; thirty-five in a fight at Daru.

Ongoing incidents: Five reports on protesting landholders blocking movements at Buka airport and seaport, detaining a UN delegation en route to Bougainville; clan fighting, including two Chimbu groups disputing an arrest, and torching of houses; ongoing surrender of weapons on Bougainville, and a murder suspect escaping at Boroko for a second time.

Commentaries: Japanese diplomats twice publicly state security issues are impeding tourism and investment; young people campaigning against violence in their local communities; Catholic clergy write in opposition to the death penalty.

Human interest and community activities (18)

Coverage in this category was noted in general editorial pages, excluding the dedicated pages or supplements given to sports (at least four out of 32-36 pages), entertainment or gossip. In the supplements area, the Post-Courier has increased general circulation with a women's supplement, the subject of some public debate (choosing between fashion or celebrity and more local focus).

Community level stories in the general pages, often labour intensive to cover, are somewhat light-on; 18 main picture stories were listed, again equally balanced between the two outlets, including: main coverage of the Hiri Moale festival; Aussie school volunteers leave with pleasant memories; PNG Olympians did the country proud; prisoners' art exhibition and gardening. 
MEDIA ETHICS AND ACCOUNTABILITY

\section{Environmentalism and Rimbunan Hijau (11)}

Much environmental news (eleven reports) is about logging. Media reports contributed to initiation of the Barnett inquiry into corruption in the forestry industry (Ausaid 2004, p. 17); investigations were frustrated, not least by the burning down of the Forestry headquarters at Hohola.

In the review period one main issue was running, reaction to a Greenpeace report published earlier, positing links between $\mathrm{RH}$ operations and corrupt practices (Greenpeace, 2004); covered in both papers; the company queried the report and talked about suing.

Of other reports in the environmental category all but one are from the Post-Courier.

Australia, security and governance issues (27)

News about relations with Australia, (27 reports, equally distributed), in the areas of national security and promotion of good governance, can produce expressions of anti-Australian feeling from politicians.

The Enhanced Cooperation Programme (ECP), despite evident public support, had detractors, e.g. a suspicious letter, 'why all this help from Australia?', and a report on the Supreme Court action brought by one provincial governor, (ultimately successful), challenging implementation of the ECP. An Australian contractor working on ECP staff facilities and charged with drinking offences, complained he was bashed by police. Six articles followed his case; three follow-up letters said expatriates should 'abide by our laws'. Two stories with pictures gave favourable treatment to Australian police arriving at Bougainville under ECP; an Australian-sourced story emphasised ECP was 'aid not intervention'.

Unnamed sources in police or security said Australian Federal Police had put bugging devices in government offices (four reports); the Internal Security Minister expressed concern over weak port and border security, suggesting close relations with Australia exposed PNG to a bigger terrorism threat.

\section{Promotional campaigns and opinion (20)}

The newspapers are public spirited in their op-ed sections and on-going promotional campaigns, and prove themselves ready to criticise the government. The Post-Courier adopts a promotional approach to certain issues, specifically HIV-AIDS, the need for road repairs where it organises volunteers to 
fill potholes, rights of women, and calls for tighter gun control. In September 2004 the newspaper received PANPA Awards, (Pacific Area Newspaper Publishers' Association), for its initiatives on gun control and women's rights. Sales increases have in part been attributed to these public interest campaigns; circulation in 2004 rose by nearly 1000 to 26,272 in September, ahead of 17,634 for The National, down by 5000 over the nine months.

Promotional features and leaders (20 noted): In the Post-Courier, PANPA Awards; guns; the $P C$ 's assistance to Mt Hagen Hospital; criticism of closeddoor power struggles around the office of the PM; a call for more information on telephone bugging ascribed to the AFP. In The National, leading articles on the corruption theme: inappropriately lenient sentence for Mapiria; support for proposed life ban on MPs convicted of Leadership Code offences; call for stronger anti-corruption laws. Other topics: criticism of 'dithering' over energy projects, the gas pipeline to Australia; concern at university fee rises, yet wanting restraint in student protests; PNG 'does not have a clue' about handling tourists.

Features space is available to guest writers, most often established figures, viz a former Chief Justice Sir Arnold Amet, a Minister Lady Carol Kidu, and the PNG representative of Transparency International Michael Manning. Political debate is often handled as a forum representing two sides. Neutral criticism of government does appear, most often in letters, e.g. eight letters in The Post-Courier and five in The National against lenient sentencing for defendants like Mapiria.

A writer to The National on 30 September 2004, as a 'former lawyer with the then Justice Department', described 'chains of stings' whereby kickbacks would be paid to 'consultants' able to tap government or state-owned enterprises, through contracts or out-of-court settlements of claims.

The Post-Courier publishes a periodical 'NPF Inquiry Scorecard', listing 83 people including police or MPs reported to the Commission of Inquiry into the National Provident Fund. The inquiry, laboriously followed since November 2002, shows limited outcomes to date.

\section{Commentaries drawn from interviews}

As might be guessed from the preceding review, much of the content of news media will unsettle the Government. The interviews brought out the main debates affecting media and government relations. 
Moves towards media controls; incidents involving hostile politicians; scope for violence against journalists.

The history of relations has been punctuated with complaints about news media and steps towards media restrictions by political leaders. There has been a parallel history of low-level incidents involving violence, harassment or intimidation. Dorney says such developments are cause for serious concern, though also part of a typically robust and open interaction, compatible with the national culture. While the interviewees broadly agreed, most on the media side still insisted persons in responsible positions had to enforce the law and expressly preserve democratic conventions.

The pattern with media restrictions divides into moves to regulate mass media with the force of law, often reflecting a sense of grievance, e.g. resentment of foreign ownership, and secondly, other kinds of incidents that demonstrate a political hostility towards media, which are persistent, leaving journalists with the sense, in the words of Peter Aitsi from the Media Council, that 'it never goes away'.

Moves on regulation listed by the Media Council: Recommendations for regulatory commissions beginning with the 1978 Kalo inquiry and re-emerging in various later exercises, notably the report tabled by Communications Minister Gabriel Ramoi in the mid-1980s, (drafting of the 1989 Media Tribunal Bill); in 1994 the Martin proposals for a regulatory National Information and Communication Council, entailing elements of licensing for journalists, the formation of which would be at the discretion of a government Minister. With this last proposal, the Media Council formed ten years earlier and representing all but a few media groups, campaigned against it, promising organised self-regulation instead. The proposal reached the stage of legislative drafting without being brought forward. With these initiatives, some originating with politicians and some in the public service, according to Aitsi 'each successive case was opposed by media people who were very capable, and able to deflect it' (AusAID 2004, p. 25; Robie, 1996; Robie, 2004, pp. 56-60, 66-77).

Informal episodes involving clashes between government and media are legion, and while politicians' complaints against aspects of news media coverage are often enough well founded, the real interest here is if they are abusive or attached to ideas of institutional control.

In March 2003, Manning as co-author of a report critical of PNG's economic management was brought before the Parliamentary Privileges Com112 PACIFIC JOURNALISM REVIEW 11 (2) 2005 
mittee. Part of the objection concerned coverage of his report in Australian news media, with two MPs talking about media regulations: 'We need legislation to punish publications or authors ... critical of the government; we need to control media houses of publications through licensing or deterrents; to deal with the issue of not informing government on articles prior to publication' (ABC/Radio Australia news 28.3.03, 3.4.03; Aitsi 2003, p. 5).

Four months later the then Deputy Prime Minister Andrew Baing, at a function attended by the media community, criticised media as dictating a foreign view, its reporting an actual encouragement to crimes like murder and rape (ABC/Radio Australia news, 17.11.04). He proposed compulsory local majority ownership for all outlets but later let the matter drop after representations from the Media Council.

In June 2004 the Prime Minister in Parliament compared the Post-Courier to disadvantage with its rival, calling it 'toilet paper'; the paper responded with a promotion delivering toilet paper to the Port Moresby and Lae general hospitals, where it is not provided to patients.

Intimidation of journalists puts the working lives of journalists into direct contact with the violence forcing its way into daily news. There is fear of intimidating behaviour committed by rogue Members of Parliament, police or other officials, or their associates. It was put to me as a visitor that where the wantok tradition is dysfunctional it can influence hostile responses to reports. In that connection, a story seen as critical of a relative or friend will be avenged, no particular distinction being made between a report written for media or a direct personal affront. It was further suggested some transfer would occur between more traditional clan or tribal loyalties and the loyalties of gangs, both exhibiting unquestioning support for a local "big man", who can well be an aggrieved politician. In the interviews, this view was concurred with not disavowed, but it was also said threats of violence were much the exception not the rule. Often enough groups with a grievance would be ready to settle for getting their story told (as related by Brian Gomez, who had to settle an angry gathering at his editorial offices over the reporting of a communal dispute).

A past litany of violent incidents includes acts of censorship, threats against journalists, or more serious events like a 1994 police attack on student protesters and journalists, detailed by Robie (1996). Bob Howarth at the Post-Courier listed several cases of journalists receiving phone threats and 
serious pressure imposed on reporters in regional offices, most seriously on Bougainville Island.

General violence not related to the news compounded difficulties in publishing the news, with attacks on newspaper street vendors or vans, armed hold-ups on the newspaper premises or hijacking of a company bus: "We spend more money on security than any division of News Limited ... We average still at least three armed attacks a week on staff; it's just part of life here'.

Other editors and journalists, including Aitsi, report incidents of staff receiving threats, and softer but insistent pressure in the form of money envelopes. Gilinik Simbir of NBC recounted incidents from the past, including contacts from supporters of a losing political party on election night, threatening violence if on-air commentary was not stopped.

Gomez, however, considered such pressure fairly unusual: 'Because we are a free media, PNG society is very understanding of the media ... The police are a bit more prone to issue threats and things ... Our police reporter said one day a police officer called and said I've got a bullet here for you. It's not common'. Ian Boden, after several years in PNG journalism, is rather dismissive: while telephone death threats are a reality, most are 'obviously phoney and designed to stir you up'.

\section{$P M$ at centre of the media storm}

Journalists express concern that periodically news media will be denounced in person by Somare, given the Prime Minister's place as the main opinion leader and effective guarantor of democratic processes. It may reflect frustration and exasperation in the government with its relentless task. Witness not only the pressures of violence and economic distress, but the weakness in the team, a high incidence of elected officials and senior officials in court, or in gaol; and news media ready to publish it all without giving much quarter. From the government perspective mere reportage may be perceived as orchestrated harm, leastwise as failure to act in reasonable solidarity with best efforts of the government. Such concern for acknowledgment is reflected in Independence Day messages from the Prime Minister about the country's many development achievements needing to be recognised.

It fits the tone of complaints like that made by Somare in November 2003. The earlier comments by Baing had been disowned as outside of gov- 
ernment policy, and then the Prime Minister responded in Parliament to an international survey on perceptions of corruption. It was reported by Shane McLeod for ABC: '(Somare: They think they are damned foreigners who are living here writing about this country). Sir Michael said he had opposed earlier proposals to control the media. (I should have said yes, we should control the press in our country). Sir Michael says developing countries need to do things that Western nations may not necessarily agree with'(ABC/Radio Australia, 11 November 2003).

An extension is the uneasy relationship between the Head of Government and the country's principal commercial media organisation. Howarth met the Prime Minister only some time after arriving to start with the PostCourier; he says their social meetings are cordial although usually taken as an occasion to complain:

My response to the PM when he has attacked me, at private meetings and things, has been that we do not report half of what goes on in this country, of corruption, lawlessness, crime, but that it is our duty to report what happens. It is not our job to put a gloss on anything ...

Howarth states his newspaper, despite its strong market position, is denied an equal share of government advertising, crucial in PNG media finances, (Rooney 2003b, p. 81).

The National takes a quieter approach, sometimes seen as a 'quality' version on account of that, but as Gomez points out, also in line for special criticism at times. 'There was quite a vigorous debate on a Bond issue and we'd been reporting views ... opposed to it. Somare got up in Parliament and said something to the effect that all this stuff The National has reported was not worth the ink and paper it was printed on ... We get up the noses of politicians quite a bit.'

Sir Peter Barter, as minister overseeing administration through provincial governments, gives a general defence of the government's bona fides in supporting free media. He sees both newspapers as supportive of the Government, the Post-Courier being 'more independent'. He excuses some of the attacks on media as part of the rough and tumble style of politics, as with the 'toilet paper' incident: 
A lot of the facts they published were incorrect ... He said your paper's only good for toilet paper; just jovial ... He was a journalist himself and he knows the journalists' game... Sometimes he gets a bit upset ... At one stage he hit the editor of The National ...but they're good friends again; just a tiff. (Question) You don't see it as dangerous? No; anyone tries to tell you otherwise it's bullshit ... The reality is politicians get very upset when you speak against them... I think the media are fairly responsible, though there are examples where even I get annoyed ... .

The minister acknowledges that it is a relationship within an elite, and concedes the same applies with television, outside the reach of most citizens: 'It is for the elite, the people who can read, who buy newspapers. Most people listen to radio. If I want to get a message out to people in the rural areas I use the radio ... We need good regional radio that broadcasts 24 hours a day.'

Despite the assurance of the government that threatening talk from those in power is not to be taken too seriously, journalists fear such statements by responsible identities might mislead irresponsible ones. Further, journalists like Aitsi of the Media Council have little time for the anxieties of the government about getting bad publicity over corruption and other issues:

Unfortunately it's of their own making. I sympathise with the condition the country's in but I don't sympathise with the individuals running it; they still need to play a bigger role, with strong leadership. There's a need for clear direction from the PM, demonstrated high levels of integrity to pull people towards them.

\section{Radio for development-consensus for broader public}

The theme of elite media excluding the bulk of the public, and the potential for radio to meet communication needs throughout the country, is well expounded in debates on PNG media needs, as in Rooney, 'news largely ignores the villages' ( 2003a, p. 127; Pamba cited in Rooney, 2003b, p. 87). The Ausaid (2004, p.18) report produced survey evidence that five times as many people owned a radio as would have a television set or purchase a daily newspaper, and recommended rebuilding the run-down NBC system to serve a broader public, on its development-orientated model. Key aspects of its recommendations, including emphasis on programme-making capacity in the development of $\mathrm{NBC}$, have been adopted for future finding. 
There is consensus among all sources canvassed for this report in support of the Ausaid proposal. Journalists like Boden and McLeod with a radio background deplore the way that NBC services, including its training, educational functions and national transmitter coverage, have come close to collapse. Support includes the backing of the official Opposition, which has also called for a national television service, increased national ownership in media generally, a fully-funded government information service, and better pay and conditions for journalists as an incentive to better performance, especially in areas like investigating corruption (Joku).

There are some reservations among the media informants about the potential for government control in a new radio system, thinking that if directed by charter to serve development needs it might thereby become politicised, leading to conflict between broadcasters and the state. Of itself however the need to rebuild radio is not a bone of contention between media and government.

\section{Criticism of reporting standards and sourcing}

Journalists in Papua New Guinea are being held to account on reporting standards, in particular over claims they do not use an adequate range of sources; claims fiercely denied by journalists able to point to obstruction of information.

Karen Haive, a senior government officer and spokesperson for the Community Development Minister, is a frustrated advocate for more developmental news. She believes journalists misunderstand the entire interests of the public, who want more information on economic development affecting daily life:

People would like to see that ... When the minister launches a project the media will come, but they do not follow through. At other times they do not give a balanced view ... They prefer propaganda for politicians, ministers or various people mostly in the upper hierarchy, who attack one another, and people don't like it...

Barter records sober complaints about some reporting, citing two key incidents. The first concerned the assassination of a senior politician on Bougainville after an erroneous press report, published and then recirculated as photocopies, wrongly connecting the man to killings on the island. The 
second concerned the breaking of an embargo on a copy of a speech prepared by an assistant, which the minister had rewritten, asking to retract the original before the cut-off time. It was potentially inflammatory, being an attack on criminal elements involved in disturbances in the Southern Highlands, though in the end it got him more public support than trouble.

\section{Information, balance and obtaining sources}

Journalists blame the restriction of sources on ineptitude or deliberate blocking of information by government. It is currently one of the most bitterly argued issues between the parties and the subject of one of two current initiatives of the Media Council.

Among some of the complaints, Howarth finds an aggressive search for a comment, even in a culture that generally enjoys an argument, will be frustrated:

Our subs block up to four stories a night because we cannot get hold of the other party to get the other view ... Most of the government don't have media reps, they don't have mobile phone contacts, some disappear off the face of the earth for weeks ... We're not overawed by the big man syndrome; as a result we're considered to be cheeky and disrespectful ...

Simbir:

They say they have a policy that only the boss can release information to the media ... so when journalists find that they cannot get in to talk with the boss, they go through the other way around, through the back door somehow. When that happens the government department or whoever will try to come down hard ... From time to time our local politicians will refuse to talk to us.

Aitsi identifies a break-down of public service structures as an avenue for corrupt practices:

Unfortunately in the public service there's a lack of information and a lack of record keeping ... There were certain times last year with particular inquiries getting to the point of finding information, where the files were burnt, or an office was burnt.

118 PACIFIC JOURNALISM REVIEW 11 (2) 2005 
Media Council, first initiative: The Media Council is proposing a pathway to agreement on handling media inquiries. It would extend its current programme of workshops and forums with key officials, to cultivate 'civil society'; aimed at building up a culture of guaranteed free flow of information, consistent with the Constitution, Section 51 (1975). It considers that information gets blocked, often due to poor resources, or an inadequate public service tradition geared to handling political information, (Aitsi, 2003, p. 5). Aitsi sees better understanding producing better service, moving towards catharsis:

Who benefits from a weakened state, a weakened system? We all know it's the rich and powerful, so they can continue to settle out of court, so they can continue to get money from the public purse with some level of impunity... I would not think just the media alone disseminating information could be the saviour. It needs change from within the system and an openness to the public.

\section{Dealing with corruption}

The present government declares for conservative fiscal management and for probity, but cannot be insulated from illegal activities within its purview. It has a quality problem in the ranks of elected politicians or officials; at times any PNG government must look for support from compromised members. It is using some institutional remedies like the hard-pressed Leadership Tribunal, and electoral reforms expected to reduce the chances of members being voted in on a very narrow segment of votes. Barter identifies some aspects of the system as encouraging malpractice, like the discretionary development funds under the control of individual MPs, now considerably reduced. He avers the government itself is honest:

No one's denying there's corruption ... It is something that I hate and detest. It makes my job extremely difficult; I get really, really angry when I have to deal with it, and I have to deal with it every day. But it is not as bad as people often make it out to be. In certain areas it is big but the bulk of the population is not involved. As far as politicians being corrupt, there have been examples but amongst my colleagues there is no-one who's dishonest ... I cannot speak of the whole Parliament but so far as Cabinet goes ... we do everything we can to stop corruption, and I assure you it is not happening with us. 
Gomez sees government facing a tough task because of inadequate material resources:

They've got First World regulatory systems and they've got Third World outcomes. If you look at the laws ... in any aspect it will be as good as or better than any developing countries; but when you come to implementation the resources are not there. It is swallowing up resources, millions of kina for commissions, inquiries ... You just have to look at the Ombudsman cases to know that the system's full of corruption.

Media Council, second initiative: The Media Council is concentrating its second current initiative on a proposal, under discussion by a committee, for cross-media reporting on corrupt practices. The proposal is for member organisations to provide a reporter on rotation to carry out investigative work, for a general pool. The exercise should reduce dependence on official sources, compound the impact of any strong stories produced, and reduce the vulnerability to intimidation of individual journalists.

\section{Rimbunan Hijau}

A strong story in Australian media, on $\mathrm{RH}$, can be traced from an anonymous English language newsletter called Masalai I tokaut. Online editions of this professionally produced work, in 2003 and 2004, accused the company of illegal logging operations, abuse of local people, and corruption of public officials, including politicians to very high levels. It details specific accusations of police being co-opted into the service of the company to deal harshly with dissident landholders or workers; of bullying and bribery to get landholder representatives to relinquish certain rights; or of the company's PNG manager invoking the name of a Minister when defying the public service over a licensing issue. It details the extent of the company's operations in several businesses including logging, retail stores and publishing through its ownership of The National. The special potency of the story is its proposal that an integrated, all-pervasive network might be exposed, corrupting the state apparatus. (Greenpeace, 2004; see Note on $\mathrm{RH}^{1}$ ).

The Masalai I tokaut claims were taken up in The Age in June 2004, (Forbes \& Fyfe, 2004), then by SBS (Special Broadcasting Service) Dateline in November, (2004). This issue is most difficult for PNG-based media because of the research resources required, need to protect sources, prospect of 
expensive and exhausting litigation, the special case of The National with its ownership, and government sensitivity. (While the SBS reporter Bronwyn Adcock obtained good access, e.g. to RH executives and senior police, she was then effectively detained in the country, her passport taken for some days).

Barter answered such criticism with a formulated defence of logging operations: that the forest industry is following more sustainable practices than previously; that much logging is necessary, using the only resource available to people of the local districts; that it provides their only protection against poverty and ill-health; and finally that campaigns mounted in foreign media are an affront to national sovereignty. He rejects the current claims about illegal logging and links to corruption.

I'm in charge of providing services to people in PNG. Our government hasn't got enough money to do it ... We have to stop people dying in the bush, improve literacy rates, improve the quality of life in rural areas ... I'm a naturalised PNG citizen but Papua New Guineans own the economy themselves; they want to be able to have an input, to do what they want with their resources ... I get upset to have international people coming in dictating to them ...

The government statement is widely canvassed and supported. For example, Boden as a leader writer on The National, keeps a distance from partisan commitments and supports conservation practices, but on forestry expressed the same position as the minister, nearly reiterating the basic statement on sustainability, the industry's vital economic importance, and disapproval of foreign involvement. He specifically derided The Age's coverage as 'nonsense'.

That is not to say The National itself accepts the tag, the 'loggers' paper', handed it in Masalai I tokaut. Gomez says the newspaper is sometimes the most outspoken on logging issues, though it has also defended the parent company, for example:

I opposed a recent World Bank draft report on logging containing a cost benefit analysis by a guy who often works in conjunction with Greenpeace, saying it was unbalanced ... There have been occasions when we have reported negative statements against RH and the PostCourier have not, and when that happens of course our RH management get very upset... 


\section{Education for journalism}

A panel discussion with fourth-year students in the journalism course at Divine Word University (Rooney 2003b; Robie 2004, pp. 152-66), on preparation for work in journalism, provided a somewhat disheartening footnote to this study. The students reflected on their involvement in well-known incidents where journalists encountered trouble with the police or other government officials, or were offered bribes. They took these disturbing experiences to be indicative of journalistic life and were concerned that parties with a grievance 'do not see journalists as neutral'. The students reflected on whether to work in journalism, conscious it was likely to be low paid, risky, so maybe not worthwhile. It was not idealistic talk about being the Fourth Estate, though there was interest also in ways to live with self-censorship, the hope of being able to work in 'development news' without being molested, and in one case a return to the ideal of a journalistic vocation, risks put into a different perspective: 'I would find it very boring sitting at a computer all day in an office. I like writing and going out and meeting people.'

\section{Conclusion}

This investigation finds a country demanding very extensive, different kinds of services from mass media. Little is on record about traditional mass communication, as distinct from modern media systems, or how the majority use media (Rooney 2003a, p. 188). There is widespread scepticism about the applicability of media systems to most people's daily lives. However the newspapers say they have reports of penetration to the most remote areas (testified by Gomez, Joku); television despite its weak penetration can have strong impacts, witness the crowds for State of Origin games; radio is popular and might be successfully revived.

PNG mass media attempts to fill many roles, directly addressing elite audiences able to pay for services; monitoring a volatile political scene; also seeking a broad, mass following through regional services, development news, promotions and entertainments.

At every point it must deal regularly with government in some way. In PNG news is not officially suppressed or directly censored. Relations dayby-day are cordial, much in the model of mutual self-interest in an elite system, punctuated with disagreements. However there are points of open discord where the interests diverge, and the chief problem areas have been examined in this report: 
- Demands on the government for access to information including effective responses to media inquiries, to permit legitimate free flow of information-countering government complaints that the news is unbalanced.

- Official corruption. The present government is not known to be corrupt but some of its employees and associates will be, viz certain Members of Parliament; disputes about the amount of media exposure given to corruption lead to a further debate, about priority that should be attached to eradicating it.

- Periodic moves by members of governments towards bringing in new media controls, generating uneasiness, suspicion, sometimes alarm in media circles.

- Verbal abuse or attempts at chastisement of journalists by public office holders. Journalists though not wanting to over-react, cannot agree to laugh this off as part of the rough and tumble. Too much of it can be seen as giving encouragement, however inadvertently, to criminals of various kinds to make war on media; to weaken it as an avenue of exposure and an aid to civil justice.

- Threats to the physical security and safety of news media organisations and their employees. Again there is a question of priority; to what extent government will go to curtail lawlessness closer to its roots; to attack social support systems available to gangsters or corrupt officials.

- The perceived power and influence of the logging company Rimbunan Hijau, the biggest company in an industry providing five percent of government revenue. The concern here is to resolve the allegations that this organisation is prepared to act illegally in its forestry operations and prone to co-opt government agents to serve its own interests. It might be done through transparency, whether openness with information on the part of the company itself or through the kind of public inquiry frequently sought by its critics. It is a highly sensitive issue for the reputation of the government and as the subject of intense media interest a potential field of severe conflict between government and media.

Individual media organisations have contested issues with the government, most prominently the ongoing promotional or 'community service' campaigns by the Post-Courier. A measured and concerted response to problems has been made through the Media Council. It has sought to keep journalism's own house in order by setting up codes of practice, and to promote change 
through its two new programmes, one designed to encourage better provision of information by government, the other to establish joint coverage of corruption issues.

The cultural climate of the country and the shared values of government and media at base look to be amenable to developing positive relations and enduring democracy. This is hampered by crisis. As said at the outset, the parties get exasperated in their relationship because of the impact of their circumstances; circumstances produced by economic pressure and the distorting factors of corruption and violence. There is a democratic forbearance on both sides and hope should exist that communication on common problems will give rise to ongoing positive change.

\section{Interviews}

Sean Dorney from the Australian Broadcasting Corporation (ABC) was interviewed in Brisbane on 3 July 2004 and the other meetings took place in Madang or Port Moresby during the two weeks under study.

Other people interviewed:

Government and Opposition

Sir Peter Barter, Minister for Inter-governmental Relations

Karen Haive, A/Assistant Director - Policy, Department of Community Development Franzjoseph Joku, Chief of Staff, Office of the Opposition Leader

\section{Journalists}

Peter Aitsi, president, Media Council of Papua New Guinea and Solomon Islands Ian Boden, lecturer, Divine Word University; leader writer for The National Brian Gomez, senior editor, formerly editor-in-chief, The National

Bob Howarth, managing director, South Pacific Post Limited

Gilinik Simbia, senior programmes officer, National Broadcasting Commission (NBC), Madang

\section{Journalism students, Divine Word University}

Joys Eggins

Aaron English

Joshua Kais

Christine Manlel

\section{Australian government and media}

Matt Anderson, counsellor, Australian High Commission, Port Moresby

Sean Dorney, Pacific correspondent, ABC

Shane McLeod, Papua New Guinea correspondent, ABC 


\section{Notes}

${ }^{1}$ Rimbunan Hijau advertises that its operations, still most heavily committed to the timber trade, extend to finance, media, IT, mining, aquaculture, agriculture, reafforestation, trading and property development; in Malaysia itself, Japan, Australia, Canada, the United States, New Zealand, Singapore, Russia, PNG, Equatorial Guinea, Gabon, Brazil, British Guyana and China. Its media interests include Malaysia's 'leading Chinese language daily newspaper', the Sin Chew Daily, and Guang Ming Daily; The National, and the Ming Pao Group operating in Hong Kong and the United States. It cites its intention in media as creating a 'global network centred around the interests and culture of Chinese people worldwide', with The National set up as an independent voice, counter to Western-owned media in PNG. (China Daily, 2005; also www.rhpng.com.pg).

Recent upsurges of interest in RH include the disclosure to Parliament in February 2005 of a report from within the PNG Department of Labour and Employment, strongly criticising conditions inside RH logging camps, later repudiated by the Department (PNG timber workers 'treated like slaves', AAP, 25.2.05; Criticisms of company based on old reports: RH, The National, 25.2.05, thenational.com.pg). A move in March by the Citicorp bank to impose new environmental protection protocols on $\mathrm{RH}$, as a client organisation, provoked applause from conversation groups and protest on the part of logging industry organisations (Ewire,www.ewire.com, 4.3.05; Business and Human Rights Resource Centre, www.business-humanrights.org, 9.3.05; Compiled.Com, www.malaysia.net, 2.5.05).

\section{References}

ABC/Radio Australia news (2003, March 28; April 3; and November 11).

Aitsi, P. J. (2003). Government and media regulations: The Papua New Guinea experience. Paper presented to the Development Research Symposium, Suva.

AusAID (2004). Papua New Guinea media for development initiative: draft design document. Canberra: Australian Government-AusAID, April.

Tan Sri Datuk Hiew King (2005, May 17). The world of Rimbunan Hijau (Advertisement). China Daily, S11.

Constitution of the Independent State of Papua New Guinea (1975, September 16). Port Moresby.

Forbes, M. and Fyfe, M. (2004, June 22). Farewell to the forests: The cash-starved Somare government is sanctioning the illegal logging of PNG's forests, and the timber is being used for Australian furniture, The Age.

Greenpeace. (2004). The untouchables: Rimbunan Hijau's world of forest crime and political patronage. Amsterdam.

Media Council of Papua New Guinea (2004). Information brief on the Media Council of Papua New Guinea. Port Moresby.

Robie, D. (1996). Fri pres: Media freedom in the Pacific. VHS, 27 min. Port Moresby: UPNG/Asia Pacific Network. 
MEDIA ETHICS AND ACCOUNTABILITY

Robie, D. (2004). Mekim nius: South Pacific media, politics and education. Suva: University of the South Pacific Book Centre.

Rooney, D. (2003a). PNG newspapers: The need for change. Australian Journalism Review. December, 25(2): pp. 121-32.

Rooney, D. (2003b). Rethinking the journalism curriculum in PNG. AsiaPacific MediaEducator, December, Issue 14, pp 76-91.

Special Broadcasting Service. (2004, November 3). PNG jungle justice. SBS Dateline.

Signis Pacific. (2001). Media the Pacific way. VHS, 35 min.

Smith, W. (2004, September 29). Interview on doing business in the developing world, World Bank report. London: BBC World Service.

Watson, J. (1998). Media communication: An introduction to theory and process. London: Macmillan.

Dr Lee Duffield is a Lecturer in Journalism at Queensland University of Technology in Brisbane. He was a journalist with Australian ABC, working in radio and television for more than 20 years, including time as an overseas correspondent. He is also a former Senior Ministerial Media Adviser with the Queensland government. This article is based on a paper presented at the Journalism Education Association (JEA) conference at Suva, Fiji, 3- 8 December 2004.

Iduffield@qut.edu.au 
Copyright of Pacific Journalism Review is the property of Auckland University of Technology and its content may not be copied or emailed to multiple sites or posted to a listserv without the copyright holder's express written permission. However, users may print, download, or email articles for individual use.

http://Mww.aut.ac.nz/depts/commstud/journ/pjrsubs.shtml 